\title{
Antioxidant, Anticancer and Anticholinesterase Activities of Flower, Fruit and Seed Extracts of Hypericum amblysepalum HOCHST
}

\author{
Cumali Keskin*
}

\begin{abstract}
Background: Cancer is an unnatural type of tissue growth in which the cells exhibit unrestrained division, leading to a progressive increase in the number of dividing cells. It is now the second largest cause of death in the world. The present study concerned antioxidant, anticancer and anticholinesterase activities and protocatechuic, catechin, caffeic acid, syringic acid, p-coumaric acid and o-coumaric concentrations in methanol extracts of flowers, fruits and seeds of Hypericum amblysepalum. Materials and Methods: Antioxidant properties including free radical scavenging activity and reducing power, and amounts of total phenolic compounds were evaluated using different tests. Protocatechuic, catechin, caffeic acid, syringic acid, p-coumaric acid and o-coumaric concentrations in extracts were determined by HPLC. Cytotoxic effects were determined using the MTT test with human cervix cancer (HeLa) and rat kidney epithelium cell (NRK-52E) lines. Acetyl and butyrylcholinesterase inhibitory activities were measured by by Ellman method. Results: Total phenolic content of $\boldsymbol{H}$. amblysepalum seeds was found to be higher than in fruit and flower extracts. DPPH free radical scavenging activity of the obtained extracts gave satisfactory results versus butylated hydroxyanisole and butylated hydroxytoluene as controls. Reducing power activity was linearly proportional to the studied concentration range: 10-500 $\mu \mathrm{g} /$ $\mathrm{mL} \mathrm{LC}_{50}$ values for $\mathrm{H}$. amblysepalum seeds were 11.7 and 2.86 respectively for HeLa and NRK-52E cell lines. Butyryl-cholinesterase inhibitory activity was $76.9 \pm 0.41$ for seed extract and higher than with other extracts. Conclusions: The present results suggested that $H$. amblysepalum could be a potential candidate anti-cancer drug for the treatment of human cervical cancer, and good source of natural antioxidants.
\end{abstract}

Keywords: Hypericum amblysepalum - antioxidant - cytotoxic - anticholinesterase

Asian Pac J Cancer Prev, 16 (7), 2763-2769

\section{Introduction}

Superoxides, (radical, hydrogen peroxide, singlet oxygen and hydroxyl radical) oxygen derived species, are well known to be cytotoxic and have been implicated in the etiology of a wide array of human diseases, such as cancer (Gulam and Haseeb, 2006).

It is a well-documented fact that exposure of organisms to exogenous and endogenous factors generates a wide range of reactive oxygen species (ROS) (Baris et al., 2011). DNA that is damaged by ROS has been extensively accepted as a foremost cause of cancer, when produced in excess that plays a significant role in the pathogenesis of cancer (Conforti et al., 2005).

Cancer is an unnatural type of tissue growth in which the cells exhibit an unrestrained division, leading to a progressive increase in the number of dividing cell and it is the second largest cause of death in the world (Kanchana and Balakrishna, 2011), and it causes about $13 \%$ of all annual deaths worldwide (Karimi et al., 2014).

Plants have been used for treating various diseases of humankind and animals since ancient time. Plant-derived compounds play a significant role in the development of important anti-cancer agents (Rajandeep et al., 2011). Moreover, plants are known as an important source in the search for novel cytotoxic compounds and several polyphenolic flavonoids possess antitumor properties (Katrin, 2014). Plant-based drugs with potent anticancer effects should add to the efforts to find a cheap drug with limited clinical side effects (Kma, 2013).

The plants of genus Hypericum are growing widely in temperate regions and they have been used as traditional medicines in many countries all over the world (Atta-ur-Rahman, 2005). The genus Hypericum is represented from Flora of Turkey with 77 species (Ozen et al., 2004). Lately, there has been a rising interest in the genus Hypericum because of being the source of a variety of compounds with different biological activities (Decosterd et al., 1991). One of the most important species of this genus is $H$. perforatum $\mathrm{L}$. which has been known in traditional medicine in Turkey especially for their sedative and antiseptic effects (Ozen et al., 2004). 


\section{Cumali Keskin}

Furthermore, the genus Hypericum is a source of a variety of biologically active compounds including the phenols. Phenolic compounds have multiple biological effects, including antioxidant activity, antitumor, antimutagenic and antibacterial properties (Guanghou and Lai, 2002). The antioxidant activity is also proper in the treatment of Alzheimer disease (Frank and Gupta, 2005; Resende et al., 2008). It was showed that the deficiency of the natural antioxidant, vitamin E, improved Alzheimer disease in a mouse experiments (Nishida et al., 2006).

Methanolic extract obtained from the aerial parts of Hypericum plants characteristically contains hypericins, hyperforins and other phenolic compounds (Barnes et al., 2001). Hypericum species are particularly rich in phenolics, caffeic acid, chlorogenic acid, proanthocyanidin (dimers and oligomers of catechin and epicatechin), prenylated derivatives of phloroglucinol and flavonoids, hyperin, rutin, quercitrin, isoquercitrin and bis-apigenins (Mojca et al., 2005). Phenolic compounds are important for their contribution to the colour, sensory attributes, nutritional value and antioxidant properties of plants (Christie et al., 1994). Polyphenol antioxidants have protective effects against cardiovascular, inflammatory and neurological diseases, as well as cancers (Lu and Foo, 1997; Bandoniene and Murkovic, 2002).

Herein, the antioxidant, anticancer, anticholinesterase activities, and HPLC analysis in view of individual phenolic compounds of different parts (flowers, fruits and seeds) methanol extracts of Hypericum amblysepalum HOCHST were investigated in detail.

\section{Materials and Methods}

\section{Instrumentation}

Perkin Elmer Lambda 25 ultraviolet-visible spectrophotometry (PerkinElmer, Inc., Shelton, CT, USA) was used for measurements. Microplate spectrophotometer system (BioTek ${ }^{\circledR}$ Epoch Microplate Spectrophotometer, Winooski-USA) was used for MTT cytotoxicity tests.

\section{Collection of plant material}

The genus Hypericum is a rich source of biologically active compounds, especially hypericin and various phenolic and other bioactive compounds. The amount of these compounds in plant tissues vary among plant parts and during the growing season. To verify the variation for H. amblysepalum, wild-growing plants were harvested at three different stages from April to August: flowering, fruiting and seeding. Plant materials were collected from vicinity of Mardin (Bakirkiri/Bakakri). It is located $37^{\circ} 19^{\prime}$ north latitude and $40^{\circ} 44^{\prime}$ east longitude at an altitude of 953 masl. Voucher specimens (H. amblysepalum flowers, fruits and seed) were deposited at the Mardin Artuklu University Herbarium (2013-2-MAU), Mardin, Turkey. Taxonomic identification of plant materials was confirmed by Dr. Cumali Keskin from the same institution and Dr. A. Selcuk Ertekin from the Dicle University.

\section{Preparation of plant extracts}

Plant materials (H. amblysepalum flowers, fruits and seeds) were dried for 10 days at room temperature. A total of $20 \mathrm{~g}$ of each dried material were ground in a grinder with a 2-mm- diameter mesh and then incubated into a glass flask with $200 \mathrm{~mL}$ (99\%) methanol for 3 days under magnetic stirrer. After it was filtrated, the methanol was removed on rotary evaporator. Approximately, $2 \mathrm{~g}$ of the crude methanol extracts of $H$. amblysepalum flower, fruit and seed were obtained and kept in dark and airtight glass bottles at $4^{\circ} \mathrm{C}$ until it was used.

\section{HPLC analysis}

The phenolic compounds in methanolic extracts of $H$. amblysepalum flower, fruit and seed were determined by using the HPLC equipped with an integrated system with an Agillent 1260 Infinity HPLC-DAD. Data were analysed by using the Agilent Chem Station revision B.04.01 software (Agilent). The chromatographic separation was achieved with the Agillent ZORBAX reverse phase C18 column $(250 \times 4,6-5 \mu \mathrm{m})$ thermostated at $35^{\circ} \mathrm{C}$. For gradient elution, two solvents were used: One of these consists of acetic acid-water $(2: 98 \mathrm{v} / \mathrm{v})$ and the other was consists of only methanol. $10 \mathrm{mg}$ of crude extract was dissolved in $10 \mathrm{~mL}$ methanol for each samples to achieve a concentration of $1 \mathrm{mg} / \mathrm{mL}$. After filtering $0.45 \mu \mathrm{m}$ membrane filter than it was injected to HPLC to determine their phenolic compounds. The injection volume was 20 $\mu \mathrm{L}$ and detection was carried out in a DAD, using $280 \mathrm{~nm}$ as the preferred wavelength.

\section{Assay for total phenolics}

The amount of total phenolic content in obtained extracts were determined by the Folin-Ciocalteu method (Slinkard \& Singleton, 1997). Additionally, $0.2 \mathrm{~mL}$ of sample solution $(2 \mathrm{mg} / \mathrm{mL})$ was introduced into a test tube containing $1 \mathrm{~mL}$ of Folin-Ciocalteu reagent and 2 $\mathrm{mL}$ of $\mathrm{Na}_{2} \mathrm{CO}_{3}(7.5 \%)$. The final volume was brought up to $7 \mathrm{~mL}$ with deionised water. After $2 \mathrm{~h}$ incubation at room temperature, the absorbance was measured at $765 \mathrm{~nm}$ with a spectrophotometer. The total phenolic content was expressed as a gallic acid equivalent (GAE) in microgram per gram dry plant material ( $\mu \mathrm{g} \mathrm{GAE} / \mathrm{g}$ extract).

\section{Scavenging activity on DPPH radical}

The ability of the extracts to scavenge 1,1-diphenyl2-picryl-hydrazil (DPPH) (Sigma Aldrich, St. Louis, MO, USA) was determined by using the reported procedure, (Shimada et al., 1992). Briefly, $0.1 \mathrm{mM}$ solution of the DPPH in ethanol was prepared. Then, $1 \mathrm{~mL}$ of this solution was added to $3 \mathrm{~mL}$ of each extract solution at different concentrations $(10-500 \mu \mathrm{g})$. The mixture was shaken mightily and allowed to stand at room temperature for 30 $\mathrm{min}$. Then, the absorbance was measured at $517 \mathrm{~nm}$ with a spectrophotometer. Lower absorbance of the reaction mixture showed higher free radical scavenging activity. The radical scavenging activities were calculated from the following equation (Dorman and Hiltunen, 2004):

DPPH scavenging activity, $\%=\left(\frac{\mathrm{A}_{517} \text { of control }-\mathrm{A}_{517} \text { of sample }}{\mathrm{A}_{517} \text { of sample }}\right) \times 100$

Reducing power activity

The reducing power activities of methanol extracts of $H$. amblysepalum flowers, fruits and seeds were determined 
Antioxidant, Anticancer and Anticholinesterase Activities of Flower, Fruit and Seed Extracts of Hypericum amblysepalum according to the method of Oyaizu, (1986). In addition, 1 $\mathrm{mL}$ of extract solution was mixed with phosphate buffer (2.5 mL, 0.2 M, pH 6.6) and potassium ferricyanide $(2.5$ $\mathrm{mL}, 1 \% \mathrm{w} / \mathrm{v})$. Mixed solution was incubated at $50^{\circ} \mathrm{C}$ for $20 \mathrm{~min}$. then $2.5 \mathrm{~mL}$ of $10 \%$ trichloroacetic acid was added to the solution. A portion $(2.5 \mathrm{~mL})$ of TCA $(10 \%)$ was added to the mixture, which was then centrifuged for $10 \mathrm{~min}$ at $3000 \mathrm{rpm}$. The upper layer of solution $(2.5 \mathrm{~mL})$ was mixed with distilled water $(2.5 \mathrm{~mL})$ and $\mathrm{FeCl}_{3}(0.5$ $\mathrm{mL}, 0.1 \%)$, and the absorbance was measured at $700 \mathrm{~nm}$ in a spectrophotometer. Higher absorbance of the reaction mixture demonstrated greater reducing power activity. The BHT (Butylated hydroxytoluen) and the BHA (Butylated hydroxyanisole) were used as a positive control.

\section{Anticholinesterase activity}

Acetyl and butyrylcholinesterase inhibitory activities were measured using an adaptation of the spectrophotometric method described in Ellman et al., (1961). Acetylthiocholine iodide and butyrylthiocholine iodide were used as substrates of the reaction and DTNB (5,5-dithio-bis(2-nitrobenzoic)acid) for the measurement of the anticholinesterase activity. All samples were dissolved in ethanol to prepare their stock solution at 4000 $\mu \mathrm{g} / \mathrm{mL}$ concentration.

Aliquots of $150 \mathrm{~mL}$ of $100 \mathrm{mM}$ sodium phosphate buffer ( $\mathrm{pH} 8.0$ ), $10 \mu \mathrm{L}$ of sample solution and $20 \mu \mathrm{L}$ AChE (or BChE) solution were mixed and incubated for $15 \mathrm{~min}$ at $25^{\circ} \mathrm{C}$, and $10 \mu \mathrm{L}$ of DTNB was added. The reaction was then initiated by the addition of $10 \mu \mathrm{L}$ acetylthiocholine iodide (or butyrylthiocholine iodide). The final concentration of the tested solutions was 200 $\mu \mathrm{g} / \mathrm{mL}$. The hydrolysis of these substrates were monitored using a BioTek Power Wave XS by the formation of yellow 5-thio-2-nitrobenzoate anion as the result of the reaction of DTNB with thiocholine, released by the enzymatic hydrolysis of acetylthiocholine iodide or butyrylthiocholine iodide, at a wavelength of $412 \mathrm{~nm}$. The experiments were carried out in triplicate. Galanthamine was used as a standard drug and the percentages of inhibition were calculated by using the following equation:

$$
\text { Inhibition, } \%=\frac{A_{\text {control }}-A_{\text {sample }}}{A_{\text {control }}} \times 100
$$

\section{Cell lines, culture treatments}

The cytotoxic effect of plants methanol extracts were determained by using MTT test on human cervix cancer (HeLa) and rat kidney epithelium cell (NRK-52E) lines. NRK-52E (ATCC CRL-1571) and HeLa (ATCC CCL-2) were cultured according to the manufacturer's protocols. Following steps were carried out for both cells and the cells were seeded at 104 cells/100 $\mu 1$ into each well of 96-well plates. After the $24 \mathrm{~h}$ of incubating period, the culture medium was abolished. Then the extracts were added to the wells in various concentrations.

The exposure concentrations were determined as $\mu \mathrm{g} /$ $\mathrm{mL}$ for the extracts. After the $24 \mathrm{~h}$ of incubation with the extracts, the MTT cytotoxicity test was performed to determine the anticancer activity of plant methanol extracts.

\section{MTT cytotoxicity test}

The test principle is that MTT, formed 3-[4,5-dimethylthiazol-2-yl]-2,5-diphenyl-tetrazolium bromide and yellow coloured water soluble tetrazolium salt, is reduced to an insoluble purple formazan product by the mitochondrial succinate dehydrogenase, which belongs to the mitochondrial respiratory chain and is only active in viable cells, in the presence of an electron coupling reagent. The protocol was performed according to the method of Alley et al (1988). The absorbance was recorded at $590 \mathrm{~nm}$ by using microplate spectrophotometer system. In every test, the negative (untreated, culture medium) and the solvent (1\% DMSO) controls were used. For each extract, four concentrations were tested in triplicates and each test was repeated twice. The $50 \%$ inhibition concentration $\left(\mathrm{LC}_{50}\right)$ was used for cytotoxic activities. The $\mathrm{LC}_{50}$ value was expressed as the concentration of sample caused an inhibition of $50 \%$ in enzyme activities in cells. In calculation, the absorbance values of samples were compared with the absorbance values of solvent controls after all absorbance values were corrected by subtracting the absorbance of blank. In MTT test, a dose-response curves was constructed and $\mathrm{LC}_{50}$ calculated according to the below formula as the percentages of solvent controls;

$$
\text { Inhibition, } \%=\left(\frac{\text { corrected mean } A_{\text {sample }}}{\text { corrected mean } A_{\text {solvent control }}}\right) \times 100
$$

$\mathrm{LC}_{50}$ values are defined as the concentrations of test compounds required to reduce the absorbance to $50 \%$ of the control values.

\section{Statistical method}

The assays were conducted in triplicate $(n=3)$ and after calculating the mean $\pm \mathrm{SD}$, the results were compared using Student's t-test. A P value of less than 0.05 was considered significant.

\section{Results and Discussion}

Total phenolic contents of flower, fruit and seed extracts of $H$. amblysepalum were determined as the gallic acid equivalents (GAE). The results from regression equation of the calibration curve $(y=0.008 x+0.004$, $\mathrm{R} 2=0.9980$ ), determined as the gallic acid equivalents per $1.0 \mathrm{mg}$ of extract ( $\mu \mathrm{g} \mathrm{GAE} / \mathrm{mg}$ extract). The results of total phenolic contents of flower, fruit and seed methanolic extracts of $H$. amblysepalum were $115.8 \pm 1.4,135.8 \pm 0.9$ and $154.5 \pm 0.8$, respectively. The highest phenolic content was determined in seed extract whereas the lowest was detected in flower extract.

The antioxidant activity in flower, fruit and seed methanol extracts of $H$. amblysepalum was initially determined using the DPPH assay and reducing power activity. Inhibition (\%) of DPPH free radical scavenging of the flower, fruit and seed methanolic extracts of $H$. amblysepalum and BHA, BHT as control were presented in Table 1. DPPH is a commercial oxidizing stable free radical, which is readily reduced by antioxidants. Increased reduction of DPPH is related to the high scavenging activity given by particular sample (Molyneux, 2004). 
Table 1. Inhibition (\%) of DPPH Free Radical Scavenging and Reducing Power Activities of the Flower, Fruit and Seed Methanolic Extracts of $H$. amblysepalum and BHA, BHT as Control (n=3, mean \pm standard deviation)

\begin{tabular}{|c|c|c|c|c|c|c|c|c|c|c|}
\hline \multirow{3}{*}{$\begin{array}{l}\text { Concen- } \\
\text { tration } \\
(\mu \mathrm{g} / \mathrm{mL})\end{array}$} & & \multicolumn{4}{|c|}{ DPPH free radical scavenging activity (\%) } & \multicolumn{5}{|c|}{ Reducing power activity } \\
\hline & \multicolumn{3}{|c|}{ H. amblysepalum } & \multicolumn{2}{|c|}{ Control } & \multicolumn{3}{|c|}{ H. amblysepalum } & \multicolumn{2}{|c|}{ Control } \\
\hline & Flower & Fruit & $\overline{\text { Seed }}$ & $\overline{\mathrm{BHA}}$ & $\overline{\mathrm{BHT}}$ & Flower & Fruit & $\overline{\text { Seed }}$ & $\overline{\mathrm{BHA}}$ & BHT \\
\hline 10 & $20.20 \pm 1.71$ & $24.46 \pm 1.71$ & $25.24 \pm 2.70$ & $73.03 \pm 0.49$ & $84.4 \pm 0.31$ & $0.28 \pm 0.01$ & $0.27 \pm 0.04$ & $0.25 \pm 0.01$ & $0.18 \pm 0.01$ & $0.13 \pm 0.02$ \\
\hline 20 & $29.31 \pm 2.40$ & $29.31 \pm 2.40$ & $31.14 \pm 0.35$ & $80.23 \pm 0.50$ & $83.3 \pm 0.10$ & $0.32 \pm 0.02$ & $0.27 \pm 0.01$ & $0.27 \pm 0.03$ & $0.36 \pm 0.02$ & $0.24 \pm 0.01$ \\
\hline 50 & $31.14 \pm 3.04$ & $40.33 \pm 3.04$ & $41.54 \pm 3.88$ & $81.53 \pm 0.10$ & $86.3 \pm 0.23$ & $0.29 \pm 0.01$ & $0.29 \pm 0.05$ & $0.31 \pm 0.04$ & $0.63 \pm 0.01$ & $0.40 \pm 0.03$ \\
\hline 100 & $43.10 \pm 0.80$ & $58.20 \pm 0.80$ & $61.14 \pm 0.68$ & $82.24 \pm 0.39$ & $87.0 \pm 0.23$ & $0.34 \pm 0.04$ & $0.37 \pm 0.02$ & $0.42 \pm 0.04$ & $0.85 \pm 0.05$ & $0.57 \pm 0.03$ \\
\hline 250 & $66.00 \pm 0.62$ & $76.32 \pm 0.62$ & $80.40 \pm 1.32$ & $85.95 \pm 0.12$ & $90.1 \pm 0.43$ & $0.41 \pm 0.03$ & $0.41 \pm 0.03$ & $0.47 \pm 0.02$ & $1.17 \pm 0.09$ & $0.85 \pm 0.05$ \\
\hline 500 & $89.07 \pm 0.24$ & $83.17 \pm 0.24$ & $84.13 \pm 0.53$ & $86.19 \pm 0.57$ & $97.3 \pm 0.84$ & $062 \pm 0.01$ & $0.66 \pm 0.03$ & $0.63 \pm 0.01$ & $1.60 \pm 0.11$ & $1.10 \pm 0.07$ \\
\hline
\end{tabular}

Table 2. Comprehensive Biological Evaluation in View of Antioxidant, Anticancer, Anticholinesterase Activities

\begin{tabular}{|c|c|c|c|c|c|c|c|c|c|}
\hline Plant & Fraction & $\begin{array}{l}\text { Total phenolic con- } \\
\text { tents }\end{array}$ & $\begin{array}{l}\text { Inhibi- } \\
\text { tion } \\
(\%) \text { of } \\
\text { DPPH }\end{array}$ & $\begin{array}{l}\text { Reduc- } \\
\text { ing } \\
\text { power } \\
\text { activi- } \\
\text { ties }\end{array}$ & $\begin{array}{l}\mathrm{LC}_{50} \\
(\mathrm{mg} / \mathrm{mL}) \\
\text { in HeLa } \\
\text { cells }\end{array}$ & $\begin{array}{l}\mathrm{LC}_{50} \\
(\mathrm{mg} / \mathrm{mL}) \\
\text { in NRK- } \\
52 \mathrm{E} \text { cells }\end{array}$ & $\begin{array}{l}\text { Inhi- } \\
\text { bition } \\
\%, \\
\mathrm{AChE} \\
(\mu \mathrm{g} / \\
\mathrm{mL})\end{array}$ & $\begin{array}{l}\text { Inhibi- } \\
\text { tion \%, } \\
\text { BChE } \\
(\mu \mathrm{g} / \\
\mathrm{mL})\end{array}$ & Ref. \\
\hline $\begin{array}{l}\text { Platycodon } \\
\text { grandiflorum }\end{array}$ & Root extract & $\begin{array}{l}4.80 \pm 0.26 \mathrm{mg} / \mathrm{g} \text { fer- } \\
\text { rulic acid equilavent }\end{array}$ & $>60$ & & $69.1^{\mathrm{a}}$ & $53^{\mathrm{b}}$ & - & - & c \\
\hline $\begin{array}{l}\text { Prunus ma- } \\
\text { haleb L. }\end{array}$ & Seed extraxt & $\begin{array}{l}75.7 \pm 0.18 \mathrm{mg} \\
\mathrm{GAE} / \mathrm{g}\end{array}$ & 44.3 & - & - & - & 52.1 & 86.2 & d \\
\hline $\begin{array}{l}\text { Achillea cap- } \\
\text { padocica }\end{array}$ & Total extract & $\begin{array}{l}101.95 \pm 2.68 \mu \mathrm{g} \\
\mathrm{PEs} / \mathrm{mg}\end{array}$ & $>60$ & - & - & - & $\begin{array}{r}22.70 \\
\pm 1.21\end{array}$ & $\begin{array}{c}70.62 \pm \\
1.57\end{array}$ & $\mathrm{e}$ \\
\hline $\begin{array}{l}\text { Cassia (Senna } \\
\text { bicapsularis) }\end{array}$ & Flower extract & $\begin{array}{l}26223.78 \pm 450.3 \mathrm{mg} \\
\mathrm{GAE} / 100 \mathrm{~g}\end{array}$ & 99.51 & - & - & - & - & - & $\mathrm{f}$ \\
\hline $\begin{array}{l}\text { Hibiscus }(H i- \\
\text { biscus rosa- } \\
\text { sinensis L.) }\end{array}$ & Flower extract & $\begin{array}{l}4598.16 \pm 106.8 \mathrm{mg} \\
\mathrm{GAE} / 100 \mathrm{~g}\end{array}$ & 83.08 & - & - & - & - & - & $\mathrm{f}$ \\
\hline $\begin{array}{l}\text { Pomegranate } \\
\text { (Punica gra- } \\
\text { natum L.) }\end{array}$ & $\begin{array}{l}\text { Seed, leaf, } \\
\text { flower, peel } \\
\text { extracts }\end{array}$ & $\begin{array}{l}85.60 \pm 4.87 \mu \mathrm{g} \\
\mathrm{GAE} / \mathrm{mg} \text { extract as } \\
\text { polyphenol }\end{array}$ & 21 & $\begin{array}{c}337.84 \\
\pm \\
38.93\end{array}$ & - & - & - & - & $\mathrm{g}$ \\
\hline $\begin{array}{l}\text { H. amblyse- } \\
\text { palum }\end{array}$ & $\begin{array}{l}\text { Seed, flower, } \\
\text { fruit extracts }\end{array}$ & $\begin{array}{l}154.5 \pm 0.8 \mu \mathrm{g} \text { GAE} / \\
\text { mg extract }\end{array}$ & 89.07 & $\begin{array}{c}0.66 \pm \\
0.03\end{array}$ & 11.67 & 4.39 & $\begin{array}{r}20.39 \\
\pm 0.43\end{array}$ & $\begin{array}{c}76.89 \pm \\
0.41\end{array}$ & $\begin{array}{l}\text { This } \\
\text { study }\end{array}$ \\
\hline
\end{tabular}

${ }^{\mathrm{a}}$ The human hepatoma cancer cell line (HepG2); ${ }^{\mathrm{T}}$ The human colon cancer cell line (HT-29); ${ }^{\mathrm{C}} \mathrm{Lee}, \mathrm{Hwang}, \mathrm{Lim},(2004)$; ${ }^{\mathrm{d} O s k o u e i a n}$ et al., (2012); ${ }^{\mathrm{e}}$ Ertas et al., (2014); ${ }^{\mathrm{f}}$ Mak et al., (2013); ${ }^{\mathrm{g}}$ Elfalleh et al., (2012)

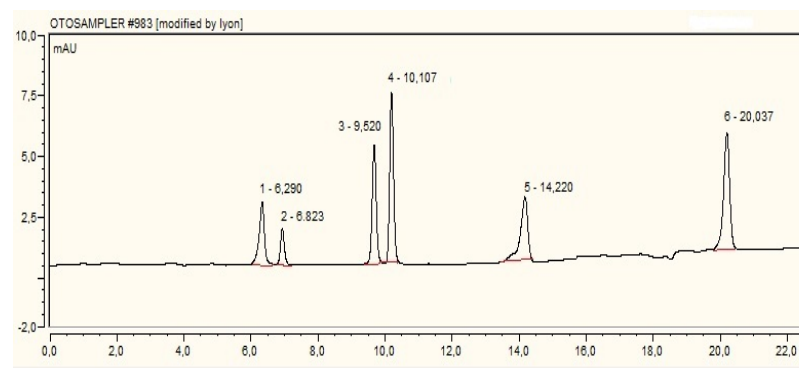

Figure 1. Representative Chromatogram of Standard Mixture of Phenolic Compounds. 1: Protocatechuic $\left(t_{R}: 6.290\right), 2:$ Catechin $\left(t_{R}: 6.823\right), 3:$ Cafeic acid $\left(t_{R}: 9.520\right)$, 4: Syringic $\left(\mathrm{t}_{\mathrm{R}}: 10.107\right), 5$ : p-coumaric acid $\left(\mathrm{t}_{\mathrm{R}}: 14.220\right), 6$ : o-coumaric acid (tR: 20.037)

Extracts and controls were subjected to the procedurein the concentrations range of $10-500 \mu \mathrm{g} / \mathrm{mL}$. Linear increasing in activities was observed with increasing concentrations. It was found that the seed extracts had higher activity at lower concentration while flower extract had more activity at higher concentrations. Approximately $30 \%$ activity was observed versus BHA and BHT at lower concentrations whereas extracts showed comparable activities at higher concentrations. The antioxidant activity in DPPH assay is related to the amount of the total phenolic compounds of the plants (Katalinic, 2006). However, the total phenolics content does not incorporate all the antioxidants. In addition, synergism between the antioxidants in the mixture makes the antioxidant activity not only depend on the concentration, but also on the structure and the interaction between the contained antioxidants (Brighente, 2007).

As a parameter of antioxidant activity reducing power is the reducing ability of extract components. In the presence of reducing agents in extract, reduction of the $\mathrm{Fe}^{3+} /$ ferricyanide complex to ferrous $\left(\mathrm{Fe}^{2+}\right)$ form. Thus, it can be assume that the presence of reductants (i.e. antioxidants) in $H$. amblysepalum extracts causes the reduction of the $\mathrm{Fe}^{3+} /$ ferricyanide complex to the ferrous form. A higher absorbance indicates greater reducing power ability (Gordon, 1990). The intensity of color resulting from reducing of ferric ions depends on the reducing potential of the compounds present in the extracts. The intensity of the color reflects the absorption, 
Antioxidant, Anticancer and Anticholinesterase Activities of Flower, Fruit and Seed Extracts of Hypericum amblysepalum

which is parallel to antioxidant activity (Zou et al., 2004).

Representative reducing power activities of controls and fractional extracts are presented in Table 1. It is clear to conclude that reducing power activities decreased with the sequence of seed, fruit and flower. BHA and BHT were employed as control and activities of extracts were found as lower than them. Reducing power activity of seed methanolic extract of $H$. amblysepalum was $0.63 \pm 0.01$.

The cytotoxic effect of plants methanol extracts were assessed by using MTT cytotoxic test on human cervix cancer, HeLa (an immortal cell line used in cervical cancer research), and rat kidney epithelium cell, NRK$52 \mathrm{E}$, lines. The growth arrest of fruit, flower and seed methanolic extracts of $H$. amblysepalum in HeLa cells was determined by MTT assay, and treatment with extracts for $24 \mathrm{~h}$ induced dramatic cell growth inhibition. There was not any remarkable results were observed in the case of flower extract of $\mathrm{H}$. amblysepalum. The $\mathrm{LC}_{50}$ values of fruit and seed extracts were 4.12 and $11.67 \mu \mathrm{g} /$ $\mathrm{mL}$ versus HeLa cell line. The highest cytotoxic activity was observed on NRK-52 cells by seed methanol extract as $2.86 \mu \mathrm{g} / \mathrm{mL}$. Probably, the cytotoxic activity might be due to its a range of phytochemical constituents and other types of anticancer compounds, which are present in the methanol extracts. Another mechanism that may responsible for the cytotoxic effect could be the synergistic effect of bioactive compounds, which are present in the extract. (Arullappan et al., 2014). The anticancer activity of the extracts in HeLa and NRK-52E cells is explicit and the MTT assay suggests a mitochondrial involvement. The Ellman's method was employed for determination of the AChE and BChE inhibitory activities. The results regarding anticholinesterase activities in view of AChE and $\mathrm{BChE}$ of the fruit, flower and seed extracts of $H$. amblysepalum and galantamine. Galantamine was used as a positive control, which is used for the treatment of Alzheimer's disease. There was not any activity observed for flower and fruit extracts whereas the seed extracts showed $20.39 \pm 0.43 \%$ inhibitor activity against the AChE. However, an important activity was observed versus to the BChE. The highest activity was observed in case of the seed extract whereas the lowest activity was observed for fruit extract versus the BChE inhibition. The seed methanol extract possessed the close inhibitory activity versus butyrylcholinesterase $(76.89 \pm 0.41 \%)$ as compared with a reference compound, galanthamine $(81.83 \pm 0.26 \%)$, at $200 \mathrm{mg} / \mathrm{mL}$ concentration.

In all the cases, the galantamine showed higher activity than extracts of $H$. amblysepalum for $\mathrm{AChE}$ and $\mathrm{BChE}$. The difference behavior of extracts versus AChE and $\mathrm{BChE}$ inhibitory activity could be attributed to their individual bioactivities.

HPLC is a column chromatographic technique that can be used for the separation of compounds in complex mixture and identification/quantification by a detector positioned in the exit of the analytical column. As a versatile, robust, and widely used technique, the HPLC was used for the identification and determination of protocatechuic acid, catechin, caffeic acid, syringic acid, p-coumaric acid and o-coumaric concentrations in fractional extracts of $H$. amblysepalum. A representative chromatogram of standard mixture of phenolic compounds was given in Figure 1. The concentrations of selected compoundswere varied in different fractions of $\mathrm{H}$. amblysepalum. The protocatechuic acid levels of flower, fruit and seed methanol extracts were found as 12.45, 11.71 and $1.74 \mathrm{mg} / \mathrm{kg}$ respectively. In addition, the catechin levels of flower, fruit and seed methanol extracts were determined as $10.99,9.87$ and $90.37 \mathrm{mg} / \mathrm{kg}$ respectively. The protocatechuic acid and catechin concentrations were found as nearly same level in flower and fruit extracts whereas important difference was observed for seed extract. Caffeic acid, and o-coumaric acid were not detectable levels in extract samples. However, p-coumaric acid only detected in flower methanolic extracts $(0.92 \mathrm{mg} /$ $\mathrm{kg}$ ). p-coumaric acid is of great interest partly due to its chemoprotectant and anti-oxidant properties (Torres and Rosazza, 2001).

Anticancer, antiallergy and antioxidant activities of catechin were reported by Kondo et al. (2000). It was reported in literature that protocatechuic acid was able to inhibit the growth of bacteria such as Escherichia coli (Chao and Yin, 2009). Moreover Lou et al. (2012) are reported that $\mathrm{p}$-coumaric acid has strong bactericidal activity. Thus it could be concluded that antibacterial activity of flowers, fruits and seeds methanol extracts of $H$. amblysepalum is possible. It is known that catechin and p-coumaric acid have free radical scavenger activity (Padam et al., 2013; Kadoma and Fujisawa, 2008). Thus, the catechin concentrations of extract verified the DPPH free radical scavenging activities of them.

Comprehensive evaluation in view of biological activity parameters was presented in Table 2. It could be possible to conclude that $H$. amblysepalum presented comparable activity in view of total phenolic, antioxidant, anticancer (against HeLa and NRK-52E cells) and anti cholinesterase (inhibitions of AChE and BChE).

This study reports antioxidant, anticancer, anticholinesterase activities of fruit, flower and seed methanol extracts of $H$. amblysepalum according to the seasonal variations and phenolic compounds of each plant parts were determined by HPLC. Additionally, it was found that the biological activities of individual plant parts extracts were at different levels and the high level of phenolic content confirmed the antioxidant activity. By considering the anticholinesterase activities of extracts, it could be concluded that using these extracts as alternative medicine contributes to the management of central nervous system disorders such as Alzheimer's disease or multiple sclerosis.

The anticancer activity obtained from MTT assay test results is an indicator of the possible applicability of the extracts in further in vitro and in vivo studies. Further, researches should investigate the isolation, structure elucidation and identification of the bioactive compounds and the mechanism of actions of these extracts. The HPLC analysis in view of protocatechuic acid, catechin and p-coumaric acid confirmed the biological activities of extracts. The present results suggested that Hypericum amblysepalum could be a potential candidate for developing anti-cancer drug or the treatment of human cervical cancer. 


\section{Acknowledgements}

The present work was carried out under the financial support of Mardin Artuklu University (MAÜ-BAP-12SYO-04). The author wishes to thank the reviewers and editors for their valuable comments. The author is also grateful to Dr. Mehmet Boğa, Dr. Selçuk Ertekin and Dr. Ersin Kılınc for their knowledge and experience.

\section{References}

Alley MC, Scudiero DA, Monks A, et al (1988). Feasibility of drug screening with panels of human tumor cell lines using a microculture tetrazolium assay. Cancer Res, 48, 589-01.

Arullappan S, Rajamanickam P, Thevar N, Kodimani CC (2014). In vitro screening of cytotoxic, antimicrobial and antioxidant activities of Clinacanthus nutans (acanthaceae) leaf extracts. Trop J Pharm Res, 13, 1455-61.

Avato P (2005). In Studies in Natural Products Chemistry, Eds Atta-Ur-Rahman The Netherlands: Elsevier, Vol: 30, pp. 603-34.

Bandoniene D, Murkovic M (2002). The detection of radical scavenging compounds in crude extract of Borage (Borago officinalis L.) by using an on-line hplc-dphh. J Biochem Bioph Meth, 53, 45-9.

Barnes J, Anderson LA, Phillipson JD (2001). St John's wort (Hypericum perforatum L.), review of its chemistry, pharmacology and clinical properties.J Pharm Pharmacol, 53, 583-600.

Baris D, Kizil M, Aytekin C, et al (2011). In vitro antimicrobial and antioxidant activity of ethanol extract of three Hypericum and three Achillea species from Turkey. Int $J$ Food Prop, 14, 339-45.

Brighente IMC, Dias M, Verdi, LG, et al (2007). Antioxidant activity and total phenolic content of some Brazilian species. Pharm Biol, 45, 156-61.

Chao CY, Yin MC (2009). Antibacterial effects of Roselle calyx extracts and protocatechuic acid in ground beef and apple juice. Foodborne Pathog Dis, 6, 201-6.

Christie PJ, Alfenito MR, Walbot V (1994). Impact of lowtemperature stress on general phenylpropanoid and anthocyanin pathways, enhancement of transcript abundance and anthocyanin pigmentation in maize seedlings. Planta, 194, 541-9.

Conforti F, Loizzo MR, Statti AG, et al (2007). Cytotoxic activity of antioxidant constituents from Hypericum triquetrifolium Turra. Nat Prod Res, 21, 42-6.

Decosterd AL, Hoffmann E, Kyburz R, et al (1991). A new phloroglucinol derivative from Hypericum calycinum with antifungal and in vitro antimalarial activity. Planta Med, 57, 548-51.

Dorman HJD, Hiltunen R (2004). Fe(III) reductive and free radical-scavenging properties of summer savory (Satureja hortensis L.) extract and subfractions. Food Chem, 88, 193-99.

Elfalleh W, Hannachi H, Tlili N, et al (2012). Total phenolic contents and antioxidant activities of pomegranate peel, seed, leaf and flower. J Med Plants Res, 6, 4724-30.

Ellman GL, Courtney KD, Andres V, et al (1961). A new and rapid colorimetric determination of acetylcholinesterase activity. Biochem Pharmacol, 7, 88-95.

Ertas A, Boğa M, Hasimi N, et al (2014). Antioxidant, anticholinesterase, and antimicrobial activities and fatty acid constituents of Achillea cappadocica Hausskn. et Bornm. Turk J Chem, 38, 592-99.

Frank B, Gupta S (2005). A rewiew of antioxidants and
Alzheimer's disease. Ann Clin Psychiatry, 17, 269-86.

Gordon MH (1990). The mechanism of antioxidant action in vitro: In B. J. F. Hudson ed. Food antioxidants London: Elsevier Applied Science 1-18.

Guanghou S, Lai PL (2002). Separation and determination of organic acids and phenolic compounds in fruit juices and drinks by high performance liquid chromatography. $J$ Chromatogr A, 977, 89-96.

Gulam W, Haseeb A (2006). Reactive oxygen species: role in the development of cancer and various chronic conditions. $J$ Carcinog, 5, 14.

Kadoma Y, Fujisawa S (2008). A comparative study of the radical- scavenging activity of the phenol carboxylic acids caffeic acid, p-coumaric acid, chlorogenic acid and ferulic acid, with or without 2-mercaptoethanol, a thiol, using the induction period method. Molecules, 13, 2488-99.

Kanchana A, Balakrishna M (2011). Anti-cancer effect of saponins isolated from Solanum trilobatum leaf extract and induction of apoptosis in human larynx cancer cell lines. Int J Pharm Pharm Sci, 3, 356-64.

Karimi P, Shahrokni A, Nezami Ranjbar MR (2014). Implementation of proteomics for cancer research: past present and future. Asian Pac J Cancer Prev, 15, 2433-8.

Katalinic V, Milos M, Kulusic T and Jukic M (2006). Screening of 70 medicinal plant extracts for antioxidant capacity and total phenols. Food Chem, 94, 550-7.

Katrin S (2014) Characteristic features of cytotoxic activity of flavonoids on human cervical cancer cells. Asian Pac J Cancer Prev, 15, 8007-18.

$\mathrm{Kma} \mathrm{L}$ (2013). Roles of plant extracts and constituents in cervical cancer therapy. Asian Pac J Cancer Prev, 14, 3429-36.

Lee JY, Hwang WI, Lim ST (2004). Antioxidant and anticancer activities of organic extracts from platycodon grandiflorum A. De Candolle roots. J Ethnopharmacol, 9, 409-15.

Lou Z, Wang H, Rao S, Sun J, Ma C, Li J (2012). p-Coumaric acid kills bacteria through dual damage mechanisms. Food Control, 25, 550-4.

Lu Y, Foo LY (1997). Identification and quantification of major polyphenols in apple pomace. Food Chem, 59, 187-94.

Mak YW, Chuah LO, Ahmad R, et al (2013). Antioxidant and antibacterial activities of Hibiscus (Hibiscus rosa-sinensis L.) and Cassia (Senna bicapsularis L.) flower extracts. J King Saud Uni-Sci, 25, 275-82.

Mojca S, Petra K, Majda H, et al (2005). Phenols, proanthocyanidins, flavones and flavonols in some plant materials and their antioxidant activities. Food Chem, 89, 191-8.

Molyneux P (2004). The use of stable free radical diphenylpicrylhydrazyl (DPPH) for estimating antioxidant acivity. Songklanakarin J Sci Technol, 26, 211-9.

Nishida Y, Yokota T, Takahashi T, et al (2006). Deletion of vitamin $\mathrm{E}$ enhances phenotype of Alzheimer disease model mouse. Biochem Bioph Res Co, 350, 530-6.

Oskoueian A, Haghighi RS, Ebrahimi M, et al (2012). Bioactive compounds, antioxidant, tyrosinase inhibition, xanthine oxidase inhibition, anticholinesterase and anti inflammatory activities of Prunus mahaleb L. seed. J Med Plants Res, 6 , 225-33.

Oyaizu M (1986). Studies on product of browning reaction prepared from glucose amine. Jpn J Nutr, 44, 307-15.

Ozen HC, Bashan M, Keskin C, et al (2004). Fatty acid and 3-hydroxy fatty acid composition of two Hypericum species from Turkey. Eur J Lipid Sci Tech, 106, 68-70.

Ozen HC, Bashan M, Toker Z, et al (2004). 3-Hydroxy fatty acids from the flowers of Hypericum lysimachioides var. lysimachioides. Turk J Chem, 28, 223-6.

Padam P, Acharya G, Genwali R, et al (2013). Isolation of 

catechin from acacia catechu willdenow estimation of total flavonoid content in camellia sinensis kuntze and camellia sinensis kuntze var. assamica collected from different geographical region and their antioxidant activities. Sci World, 11, 32-6.

Rajandeep K, Karan K, Harpreet K (2011). Plants as a source of anticancer agents. J Nat Prod Plant Resour, 1, 119-24.

Resende R, Moreira PI, Proenca T, et al (2008). Brain oxidative stress in a triple-transgenic mouse model of Alzheimer disease. Free Radical Biol Med, 44, 2051-7.

Shimada K, Fujikawa K, Yahara K, et al (1992). Antioxidative properties of xanthone on the auto oxidation of soybean in cylcodextrin emulsion. J Agr Food Chem, 40, 945-8.

Slinkard K, Singleton VL (1997). Total phenol analysis: Automation and comparison with manual methods. Am J Enol Viticult, 28, 49-55.

Torres J, Rosazza JPN (2001). Microbial transformations of p-coumaric acid by Bacillus megaterium and Curvularia lunata. J Nat Prod, 64, 1408-14.

Zou Y, Lu Y, Wei D (2004). Antioxidant activity of a flavonoidrich extract of Hypericum perforatum L in vitro. J Agr Food Chem, 52, 5032-9. 